\title{
THE RELATIONSHIP BETWEEN RISK \\ FACTORS FOR METABOLIC SYNDROME IN THE PHYSICALLY ACTIVE ELDERLY
}

\author{
Erika Silva Maciel ${ }^{1}$ \\ Jaqueline Girnos Sonati² \\ Dênis Marcelo Modeneze 3 \\ Guanis Barros Vilela Junior \\ Julia Santos Vasconcelos 5 \\ Roberto Vilarta ${ }^{6}$
}

\footnotetext{
1 Undergraduate Degree in Physical Education. Doctoral Degree in Nuclear Energy in Agriculture and Environment. Assistant Professor at Centro Universitário Luterano de Palmas (CEULP/ULBRA). E-mail: erikasmacie|@gmail.com

2 Undergraduate Degree in Nutrition. Doctoral Degree in Physical Education. Postdoctoral Researcher from the Faculdade de Enfermagem, Universidade Estadual de Campinas (UNICAMP). E-mail: j.girnos@uol.com.br

3 Undergraduate Degree in Physical Education. Doctoral Degree in Physical Education. Clinical Director in Physical Exercise at Corpo\&Equilíbrio. E-mail: modeneze@uol.com.br

4 Undergraduate Degree in Physical Education. Doctoral Degree in Physical Education. Professor at the Faculdade de Educação Física, Universidade Metodista de Piracicaba (UNIMEP). E-mail: guanis@ gmail.com

5 Undergraduate Degree in Food Science. Professor at Escola Superior de Agricultura "Luiz de Queiroz". E-mail: julia.vasconcelos31@gmail.com

6 Bachelor's Degree in Physiotherapy. Doctoral Degree in Life Sciences. Professor of Physical Education at Universidade Estadual de Campinas (UNICAMP). Head of the Departamento de Estudos da Atividade Física Adaptada at the Faculdade de Educação Física, Universidade Estadual de Campinas (UNICAMP). E-mail: roberto@fef.unicamp.br
} 
abstract

Aging has a significant impact on the decrease of lean body mass and physical activity level, being related to the reduction in basal metabolic rate and the increase of overweight and obesity in the elderly. The aim of this study is to identify correlations among the risk factors of metabolic syndrome (MS) from the measurement of abdominal perimeter (AP) and body mass index (BMI) with blood parameters for fasting blood glucose (FBG), total cholesterol (TC) and triglycerides (TG) in active elderly people. Measurements of weight and height were adopted to classify criteria by the World Health Organization $(\mathrm{WHO})$ and to calculate BMl. The measurement of AP was done in centimeters. Blood parameters for FBG, TC, and TG were assessed by collecting blood from the fingertip and analyzing it using the Accutrend Plus (Roche) equipment. For data analysis, the Pearson correlation coefficient between anthropometric measures (independent variables) and blood parameters (dependent variables) was calculated. Simple linear regression was applied to the significant variables (0.05\%). The BMl assessment shows $71 \%$ of the elderly were overweight and 34\% were obese. Over the cut-off point recommended, 57\% of the sample was indicated by AP. The correlation test shows evidence regarding the existence of a significant association between FBG and AP and also between AP and TG as compared to the use of BMI. The AP measurement seems to be an efficient indication of the relationship between risk factors for MS and should be incorporated into routines to assess the elderly as an indicator of abdominal obesity.

keywords

Nutritional Status. Abdominal Perimeter. Physical Activity Level. Elderly.

\section{Introduction}

Increased life expectancy has been accompanied by a higher prevalence of chronic non-communicable diseases (NCDs) in the elderly. It has been compounded by organ dysfunction, functional morphology in the natural aging process and higher frequency of disabilities (BOARDLEY et al., 2007; ELMADFA; MEYER, 2008).

Aging has a significant impact on the decrease of lean body mass and physical activity level and it is related to the reduction in basal metabolic rate and the increase of cases of overweight and obesity among the elderly 
(ELMADFA; MEYER, 2008; SONATI et al., 2010). The combination of a sedentary lifestyle and aging is usually accompanied by other health disorders, such as hypertension, insulin resistance, and dyslipidemia (MARQUES et al., 2009).

Metabolic Syndrome (MS) is identified by a group of metabolic risk factors for cardiovascular disease and diabetes mellitus type 2, showing the main components such as excess abdominal fat, atherogenic dyslipidemia, hypertension, hyperglycemia and insulin resistance, added to a proinflammatory and a prothrombotic state (RIGO et al., 2009). The criteria for the diagnosis of MS were originally proposed by the WHO in 1998, a European group for the study of insulin resistance in 1999, the US National Cholesterol Education Program - Adult Treatment Panel III (EPDETHBCA, 2001), and the International Diabetes Federation in 2005. However, the NCEP-ATP III is often applied in epidemiological studies and clinical practice worldwide, based on assessments of measures of localized fat, as opposed to the use of BMI (LEE et al., 2010).

For the diagnosis of MS, at least three of the five following components of MS have to occur concomitantly: increased abdominal circumference (AC), increased glucose while fasting, low HDL cholesterol, hypertriglyceridemia and high blood pressure (EPDETHBCA, 2001).

Health and quality of life were endangered by the MS, being more prevalent in the elderly because this part of the biological life cycle occurs at a time of drastic reduction in fat-free mass, alterations in glucose metabolism and decreased levels of high-density lipoprotein (HDL-C) (BO et al., 2009). Dyslipidemia remains among the main factors associated with MS, which include a change in levels of blood lipids, hypertension, obesity and abdominal obesity (CANKURTARAN et al., 2006).

The strong evidences that linked central obesity and cardiovascular risk show prevalence of obesity has increased in all age groups in recent decades, concomitant with population aging. Therefore, the assessment of abdominal obesity by PA is essential for the diagnosis of MS (SAAD et al., 2014).

Since aging is accompanied by a significant change in body composition, it is important to check and monitor the conditions of the nutritional status of the elderly. Moreover, abdominal obesity is commonly associated with the development of risk factors for some NCDs (SONATI et al., 2010).

General and abdominal obesity increases with aging are precursors for several cardiovascular and metabolic diseases risk factors. The elderly are the population group with the highest prevalence of cardiovascular events. Therefore, identifying the prevalence of risk factors for MS among this group is important for the possibility of taking risk control measures. In Brazil, the data on the prevalence of MS among the elderly are scarce, which justifies the 
need of a better understanding of this phenomenon in our population (RIGO et al., 2009; SAAD et al., 2014).

Thus, in order to verify the behavior of these variables in the elderly, this study aims to examine the correlation between measurements of abdominal perimeter (AP) and body mass index (BMI) with blood-test results for fasting blood glucose (FBG), total cholesterol (TC) and triglycerides (TG) in elderly people who engage in physical activity during a program conducted by the University of the Third Age (UTA).

\section{Materials and methods}

\subsection{Subjects}

The study is exploratory and cross-sectional focused on elderly men and women registered at the University of the Third Age (UTA), the Luiz de Queiroz School of Agriculture, University of São Paulo, Piracicaba, São Paulo, Brazil. A total of 350 elderly registered in the program were personally invited to participate in the survey, from which 98 elderly formed the sample that met the criteria for inclusion in the study: being enrolled in the physical activity program at the UTA, not having any type of cancer, amputation, pacemaker, or any symptoms of high blood pressure; making use of diuretics, having completed the questionnaires and being 60 years old or over and participate voluntarily in the research. The program is open to any old town and gathers various elderlies, including among these a retired professor at USP and an older with no previous ties with the university.

Self-applied protocols on identification and socioeconomic data were used for collecting variables such as gender, age in completed years, marital status, occupation, education, and the socioeconomic status divided up into eight categories (A1, A2, B1, B2, C1, C2, D, and E), in which category 'A1' is the highest and category ' $\mathrm{E}$ ' is the lowest; and using a points system that used criteria such as asset ownership, the presence of a maid, and education of the household head for the Brazilian Association of Population Research (ABEP, 2008).

The level of overall physical activity was analyzed according to the short-form and normal-week physical activity questionnaire (IPAQ), version 8, developed by the WHO (2002), which has been validated and used in Brazil (PARDINI et al., 2001) based on a joint research project between the Physical 
Fitness Laboratory Studies Center in São Caetano do Sul (CELAFISCS) of Brazil and the Center for Disease Control (CDC) of the United States of America.

Data were collected by trained researchers, researchers and students of the College of Physical Education of the University of Campinas (UNICAMP) methods. The study was approved by the Ethics Committee of the Faculty of Medical Sciences, University of Campinas (UNICAMP) (Protocol 622/2008), observing the integrity of the individual as set out in Resolution 466/2012 of the National Health Council.

\subsection{Anthropometric measurements}

Anthropometric measurements were taken in the morning prior to breakfast offered to the participants who had fasted. Body weight was measured according to international standards (GORDON et al., 1991) using a digital Healthmeter weight scale, calibrated for a load of $150 \mathrm{~kg}$ and the height was measured with a Sanny wall stadiometer with an accuracy of $0.1 \mathrm{~cm}$. The BMI was determined by dividing weight in kilograms by the square of height in $\mathrm{m} 2$.

For the BMI classification, the criteria proposed by the WHO (WHO; FAOUN, 2002) designed for adults of both genders were adopted: underweight $(\mathrm{BMI} \leq 18.5)$, recommended range $(18.5 \leq \mathrm{BMI} \leq 24.9)$, overweight $(25 \leq \mathrm{BMI} \leq 29.9)$, obesity I ( $30 \leq \mathrm{BMI} \leq 34.9)$, obese II $(35 \leq \mathrm{BMI} \leq 39.9)$, and obesity (BMI $\geq 40)$.

The measurement of abdominal perimeter (AP) was taken in centimeters using a non-elastic tape on the skin at the height of the umbilicus in the standing position and without shoes, according to the methodology in the manual for standard anthropometric measurements (CALLAWAY et al., 1988).

The Brazilian Society of Cardiology (BSC) (SPOSITO, 2007) classification criteria for abdominal obesity use the following limits: for white men of European and African descent, $\geq 94 \mathrm{~cm}$; for South Asians, American Indians and the Chinese, $\geq 90 \mathrm{~cm}$; and for the Japanese, $\geq 85 \mathrm{~cm}$. White women of European, African, South Asian, Amerindian, Chinese origins have values of $\geq 80 \mathrm{~cm}$ and those of Japanese origin, $\geq 90 \mathrm{~cm}$. Since there is a lack of consensus on cut-off points that are universally accepted for AP. Thus, we chose to use data derived from an association of AP with health risk. However, the criteria proposed by the WHO to define the cut-off point of $94 \mathrm{~cm}$ for men and $80 \mathrm{~cm}$ for women were adopted (WHO, 2002). 
The blood parameters for FBG, TC, and TG were assessed by collecting blood from the fingertip and analyzing it using the Accutrend Plus (Roche) equipment (COBAS, 2009).

Although this device underestimates the concentration value of TC of $0.26 \mathrm{mmol} / \mathrm{L}$ and overestimates the TG value of $0.16 \mathrm{mmol} / \mathrm{L}$, when compared with data obtained by conventional laboratory methods, its use confirms the accuracy and the reproducibility of the data collected (SCAFOGLIERI et al., 2012). It measures the color intensity and the reaction layer on the test strip through reflectance photometry, and calculates the concentration of each parameter in the sample using a specific algorithm for each batch. For each parameter, we used test strips, specific set reading, fasting glucose in the range of $20-600 \mathrm{mg} / \mathrm{dL}$ and total cholesterol values of $150-300 \mathrm{mg} / \mathrm{dL}$, with the values outside these ranges being adopted for the lowest or highest classification.

The data were assessed according to grading standards adopted by the BSC (2009) considering TG $\geq 150 \mathrm{mg} / \mathrm{dL}, \mathrm{TC} \geq 200 \mathrm{mg} / \mathrm{dL}, \mathrm{FPG} \geq 100 \mathrm{mg} / \mathrm{dL}$. The criterion for systemic Blood Pressure (BP) was $\geq 130 \mathrm{~mm} \mathrm{Hg}$ and for diastolic pressure, it was $\geq 85 \mathrm{~mm} \mathrm{Hg}$.

\subsection{Data analysis}

The statistical analysis consisted of a descriptive analysis based on measures of central tendency by calculating the Pearson correlation coefficient between anthropometric measurements (independent variables) and blood parameters (dependent variables). Simple linear regression was applied to significant variables $(0.05 \%)$ to predict the pattern of the regression equation. Data were assessed with the SAS statistical software, version 9.1.3 (SAS INSTITUTE, 2004).

\section{Results}

\subsection{Sample profile}

The study sample consisted mostly of aged 65-80 (average 76.8-68.2\%, aged 5.0-4.6) retired (75.8\%) married (64.2\%) women (85.3\%).

Regarding the socioeconomic level, results suggest concentrations in categories B1 (26.3\%), B2 (28.4\%), and C1 (21.1\%) as the criteria for classification by the Brazilian Association of Business and Research (ABEP) (ABEP, 2008). 
The values obtained in the studied population revealed all older people can be considered active, being classified as $60 \%$ active, $25 \%$ very active and $15 \%$ sufficiently active.

\subsection{Nutritional status}

The analysis of the anthropometric profile showed most patients (71.7\%) were found to be over the recommended range of body weight and 34.7\% presented a very high risk for obesity-related diseases. The AP results show $57 \%$ of the sample are above the AP cut-off point $(94 \mathrm{~cm}$ for men and $80 \mathrm{~cm}$ for women) proposed by the WHO and the FAOUN (2002), indicating more than half of the sample were at risk of developing chronic diseases.

\subsection{Blood parameters}

The average levels of blood parameters (Table 1) showed values within normal limits, in which $97 \%$ of the individuals had normal levels of FBG. However, results of serum lipids TG were normal in only $44 \%$ of the elderly and $36 \%$ of them had TC higher than $200 \mathrm{mg} / \mathrm{dL}$, which is a sign of dyslipidemia, according to the BSC parameters (SPOSITO, 2007).

The analysis indicated an average systolic BP of $138.24 \pm 22.81 \mathrm{mmHg}$ and $86.45 \pm 13.49 \mathrm{~mm} \mathrm{Hg}$ of diastolic BP, which are regarded as threshold values for stage 1 hypertension (SPOSITO, 2007), and also high systolic BP at 65\% in the elderly and a high diastolic BP of $54 \%$ in the group sampled.

Table 1 - Blood parameters and anthropometric profile of the elderly participants of the UTA, Piracicaba, São Paulo (2008).

\begin{tabular}{l|c|c|c|c|c}
\hline \multicolumn{1}{c|}{ Blood parameters } & minimum & maximum & average & (SD) \pm & $\mathbf{n}$ \\
\hline $\mathrm{FBG}(\mathrm{mL} / \mathrm{dL})$ & 48 & 110 & 69 & 13 & $97^{\star}$ \\
\hline $\mathrm{TC}(\mathrm{mL} / \mathrm{dL})$ & 150 & 286 & 187.5 & 31.9 & $82^{\star}$ \\
\hline $\mathrm{TG}(\mathrm{mL} / \mathrm{dL})$ & 70 & 505 & 153 & 81.7 & $76^{\star}$ \\
\hline $\mathrm{BMl}$ & 16.7 & 42.2 & 27.4 & 4.2 & 98 \\
\hline $\mathrm{AC}(\mathrm{cm})$ & 61.8 & 120 & 85.32 & 11.1 & 98 \\
\hline
\end{tabular}

* Values on which the measurement was presented as lowest or highest were not considered. 
The Pearson correlation test $(\mathrm{P})$ (Table 2) showed a significance of at least $0.05 \%$ for anthropometric variables related to TG and FBG values.

Table 2 - The Pearson correlation coefficient between blood parameters and anthropometric measurements of the elderly from the UTA, Piracicaba, São Paulo (2008).

\begin{tabular}{l|c|c}
\hline \multicolumn{1}{c|}{ Variable } & $\mathbf{R}$ & $\mathbf{P}$ \\
\hline FBG $(\mathrm{mg} / \mathrm{dL}) \times \mathrm{BMl}\left(\mathrm{kg} / \mathrm{m}^{2}\right)$ & 0.21 & 0.0335 \\
\hline $\mathrm{FBG}(\mathrm{mg} / \mathrm{dL}) \times \mathrm{AP}(\mathrm{cm})$ & 0.39 & $<0.0001$ \\
\hline $\mathrm{TC}(\mathrm{mg} / \mathrm{dL}) \times \mathrm{BMl}(\mathrm{kg} \mathrm{m})^{2}$ & -0.01 & 0.9017 \\
\hline $\mathrm{TC}(\mathrm{mg} / \mathrm{dL}) \times \mathrm{AP}(\mathrm{cm})$ & -0.01 & 0.9026 \\
\hline $\mathrm{TG}(\mathrm{mg} / \mathrm{dL}) \times \mathrm{BMl}\left(\mathrm{kg} / \mathrm{m}^{2}\right)$ & 0.28 & 0.0140 \\
\hline$T G(\mathrm{mg} / \mathrm{dL}) \times \mathrm{AP}(\mathrm{cm})$ & 0.38 & 0.0005 \\
\hline
\end{tabular}

$\mathrm{AP}=$ Abdominal Perimeter

$\mathrm{BMI}=$ Body Mass Index

$\mathrm{FBG}=$ Fasting Blood Glucose

$\mathrm{TC}=$ Total Cholesterol

$\mathrm{TG}=$ Triglycerides

Correlations were significant in relation to blood parameters, FBG, TG, and measures of $\mathrm{BMI}$ and $\mathrm{AP}$. The strongest association was observed between FBG and AP (39\%) and between TG and AP (38\%). A simple linear regression analysis (Image 1) shows the relationship of the blood parameters FBG and TG with anthropometric data, $\mathrm{BMI}$ and $\mathrm{AP}$, indicating these groups of variables have evolved similarly in the elderly sample. 

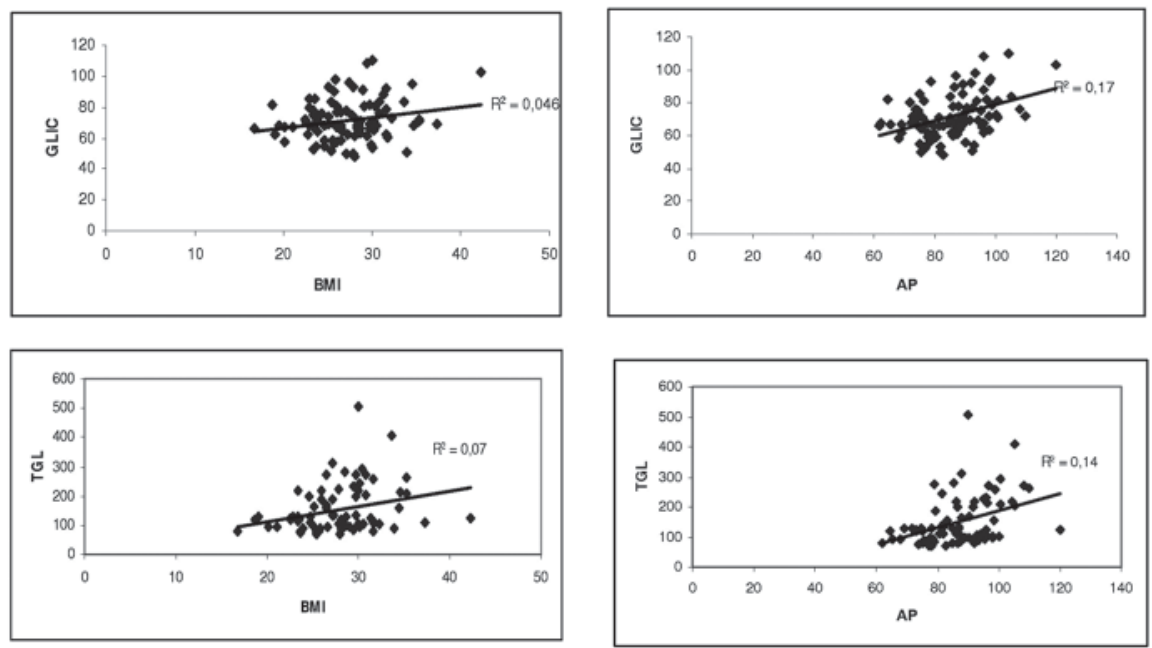

\section{Discussion}

Our study indicated AP seems to relate more adequately to the relationship between accumulation of central adipose tissue and levels of FBG and TG to assess risk factors of MS in the elderly rather than the BMI, according the statistical tests results.

It is important to emphasize abdominal obesity is the main risk factor for cardiovascular disease in the elderly. Abdominal obesity is important to be emphasized as the main risk factor for cardiovascular disease in the elderly. $\mathrm{BMI}$ and AP are indirect measurements for the efficient evaluation of overall and central adiposity, and have been associated with the occurrence arterial hypertension, dyslipidemia, and low high density lipoprotein cholesterol (HDL-C) (LEITE et al., 2009). BMI is a measure used worldwide in identifying individuals with a nutritional risk of becoming overweight and obese. It is still rarely used to assess the elderly, and is regarded as ineffective because of failing to reflect mainly the regional distribution of fat, which occurs with aging (PERISSINOTTO et al., 2002).

The anthropometric measurements, which assess central obesity, such as waist circumference, AP or waist-hip ratio and, more recently, waist-to-height 
ratio, are increasingly frequent. Further, their use has been justified by greater accuracy in assessing obesity, which appears to be a related risk factor for MS in both men and women (HUXLEY et al., 2010; LEE et al., 2008). An study involving 5,057 adults (over 40 years) found an association between abdominal obesity and metabolic abnormalities, including insulin resistance, dyslipidemia, and increased incidence of hypertension, which results in increased levels of propensity to diseases such as cardiovascular disease (LU et al., 2010). Individuals who are overweight, especially with the accumulation of abdominal fat, are more exposed to risk factors involved in MS and, therefore, have a higher risk of morbidity and mortality if these changes are not treated (REZENDE et al., 2006; TULL et al., 2005).

The individuals included in our study showed a risk condition for MS with high weight (71.7\%), central adiposity (57\%), systolic hypertension (65\%), and high TG and TC levels. The Pearson correlation between anthropometric measurements and blood suggests strong links between TG and AP (38\%), and also between FBG and AP (39\%), whereas FBG and TG correlated with $\mathrm{BMI}$ resulted in values of $28 \%$ and $21 \%$, respectively.

We found AP was the indicator of adipose tissue which correlated more strongly and with more blood variables than BMI. These results corroborate those found in another similar study (LU et al., 2010), in which the authors emphasize TG was the measure that correlated significantly with anthropometric parameters, which reinforces the importance of using measurements that assess central fat accumulation, such as AP.

The high levels of TG observed in this study may be associated with the consumption of carbohydrates, which, when consumed in excess, tend to deposit TG in form of adipose tissue. This consideration is reinforced by recent studies, which show a strong correlation between high consumption of simple carbohydrates in the diet of adults and the presence of dyslipidemia (WELSH et al., 2010) increase in carbohydrate intake associated with decreased HDL-C, elevated levels of TG, LDL-C, and its association with an increased risk of obesity, diabetes, and cardiovascular disease (WELSH et al., 2010; HOWLETT et al., 2008).

Moreover, the adoption of an active lifestyle promotes a protective effect against MS related to the effects of aging that come with the decrease in muscle mass and increased adipose tissue, especially around the abdomen, and can be mitigated themselves through the systematic practice of physical exercise (ALBERTI et al., 2006; KRAMER et al., 2009). Large variations, such as the decrease in the levels of TG $(-5.1 \%, p=0.006)$ and increased HDL-C $(9.3 \%$, $p<0.001)$, were observed after the application of an exercise program consisting 
of aerobic activity and endurance flexibility for eight months for women aged 60-79 years (MARQUES et al., 2009). However, one must be cautious in interpreting results from studies in the elderly population, considering the fact advancing age is often accompanied by a greater number of risk factors and the consequent prevalence of MS (BO et al., 2009; CANKURTARAN et al., 2006).

The use of the fingerstick test has shown good reproducibility (0.958 glucose, triglycerides $0.992,0.940$ total cholesterol) and high correlation with the laboratory method (glucose 0.952, 0.990 triglycerides, and total cholesterol 0.944). These results demonstrate the method is feasible for portable conducting research and as an alternative to the monitoring of metabolic disease and cardiovascular risk factors (COQUEIRO et al., 2014; EIZERIK, 2012).

\section{Final remarks}

The results of this study showed that assessments based on AP measurements are appropriate for studying the risk factors related to MS in the active elderly, particularly the relationship between the accumulation of central adipose tissue and levels of FBG and TG.

The AP measurement of the elderly should be considered as an indicator of adipose tissue since it is strongly correlated with a higher number of blood variables as compared to BMI.

Interventions to promote health and quality of life in the elderly population must be based on strategies that include balanced nutrition, physical activity, and systematic monitoring of the evolution of anthropometric measurements and blood tests.

However, we must take into account the limitations of this study include the fact the group was exclusively female, making it difficult to estimate the data for older men. Although data collection is easy to apply, and the results indicate the total cholesterol, they do not show cholesterol fractional values, which could be of interest for studies of the elderly population. 


\section{A RELAÇÃO ENTRE OS FATORES DE RISCO PARA A SÍNDROME METABÓLICA EM IDOSOS FISICAMENTE ATIVOS}

resumo

O envelhecimento tem um impacto significativo na diminuição de massa magra e do nível de atividade física, estando relacionado à redução na taxa metabólica basal e ao aumento de sobrepeso e obesidade em idosos. O objetivo deste estudo foi identificar correlações entre os fatores de risco da síndrome metabólica (SM) e a medição do perímetro abdominal (PA) e do índice de massa corporal (IMC) com os parâmetros sanguíneos de glicemia de jejum (GJ), colesterol total (CT) e triglicerídeos (TG) em idosos ativos. Para cálculo do IMC, foram coletadas medidas de peso e altura e adotados os critérios de classificação da Organização Mundial da Saúde (OMS). A medida do PA foi efetuada em centímetros. Os parâmetros sanguíneos de GJ, CT e TGL foram avaliados pelo método de coleta de sangue na ponta de dedo com leitura em equipamento Accutrend Plus (Roche). Para análise dos resultados, foi realizado o cálculo do coeficiente de correlação de Pearson entre as medidas antropométricas (variáveis independentes) e parâmetros sanguíneos (variáveis dependentes). A regressão linear simples foi aplicada sobre as variáveis significativas (0.05\%). A avaliação do IMC mostrou que $71 \%$ dos idosos estavam acima do peso e 34\% eram obesos. No ponto de corte recomendado, $57 \%$ da amostra foram indicados por PA. O teste de correlação mostrou evidências sobre a existência de uma associação significativa entre GJ e PA e também entre PA e TG em comparação ao uso do IMC. A medição de PA parece ser uma indicação eficaz da relação entre os fatores de risco para a SM e deve ser incorporada nas rotinas para avaliar idosos como um indicador de obesidade abdominal.

palavras-chave

Estado Nutricional. Perímetro Abdominal. Nível de Atividade Física. Idoso. 
ALBERTI, Kurt George Matthew Mayer; ZIMMET, Paul; SHAW, Jonathan. Metabolic syndrome - a new world-wide definition. A Consensus Statement from the International Diabetes Federation. Diabetic Medicine, Chichester, v. 23, n. 5, p. 469-480, May 2006.

ASSOCIAÇÃO BRASILEIRA DE EMPRESAS DE PESQUISA. Critério de Classificação Econômica Brasil. São Paulo: ABEP, 2008. Available at: <http://www.abep.org/Servicos/ Download.aspx?id=07>. Accessed on: 10 May 2013.

BO, Mario et al. Metabolic syndrome in older subjects: coincidence or clustering? Archives of Gerontology and Geriatrics, Amsterdam, v. 48, n. 2, p. 146-150, Mar./Apr. 2009.

BOARDLEY, Debora et al. The impact exercises training on blood lipids in older adults. The American Journal of Geriatric Cardiology, Greenwich, CT, v. 16, n. 1, p. 30-35, Jan./Feb. 2007.

CALLAWAY, Clifford Wayne et al. Circunferences. In: LOHMAN, Timothy G.; ROCHE, Alex F.; MARTORELL, Reynaldo (Ed.). Anthropometric Standardization Reference Manual. Champaign, IL: Human Kinetics Books, 1988. p. 39-54.

CANKURTARAN, Mustafa et al. Prevalence and correlates of metabolic syndrome (MS) in older adults. Archives of Gerontology and Geriatrics, Amsterdam, v. 42, n. 1, p. 35-45, Jan./Feb. 2006.

COBAS. Accutrend Plus: user's manual. Mannheim: Roche Diagnostics, 2009. Available at: <http://shop.skolebutik.dk/images/shop/Accutrend_Plus_OM_05340454001_V02_ Intranet_EN-USA.pdf>. Accessed on: 10 May 2013.

COQUEIRO, Aline et al. Leishmanicidal Activity of Brosimum glaziouvii (Moraceae) and Chemical Composition of the bioactive Fractions by using High-Resolution Gas Chromatography and GC-MS. Journal of the Brazilian Chemical Society, v. 25, p. 1839-1847, 2014.

EIZERIK, Dauana Pitano. Análise comparativa de dois métodos de mensuração de glicose, colesterol e triglicerídeos: sangue venoso em laboratório de bioquímica e sangue capilar em aparelho portátil Accutrend GCT ß. 2012. 59 p. Thesis (Master's Degree in Health Sciences) - Faculdade de Medicina, Universidade Federal do Rio Grande do Sul, Porto Alegre, 2012. Available at: <http://www.lume.ufrgs.br/bitstream/ handle/10183/61885/000866775.pdf>. Accessed on: 10 May 2014.

ELMADFA, Ibrahim; MEYER, Alexa L. Body composition, changing physiological functions and nutrient requirements of the elderly. Annals of Nutrition and Metabolism, Basel, v. 52, p. 2-5, Mar. 2008. Supplement 1.

EXPERT PANEL ON DETECTION, EVALUATION, AND TREATMENT OF HIGH BLOOD CHOLESTEROL IN ADULTS. Executive Summary of the Third Report of the National Cholesterol Education $\operatorname{Pr}($ NCEP) Expert Panel on Detection, Evaluation, and Treatment of High Blood Cholesterol in Adults (Adult Treatment Panel III). JAMA, Chicago, v. 285, n. 19, p. 2486-2497, May 2001. Special Communication.

GORDON, Claire C.; CHUMLEA, William Cameron; ROCHE, AlexF. Stature, recumbent length, weight. In: LOHMAN, Timothy G.; ROCHE, Alex F.; MARTORELL, Reynaldo (Ed.). Anthropometric Standardization Reference Manual. Champaign, IL: Human Kinetics Books, 1991. p. 3-8.

HOWLETT, John; ASHWELL, Margaret. Glycemic response and health: summary of a workshop. The American Journal of Clinical Nutrition, Bethesda, MD, v. 87, n. 1, p. 212S-216S, Jan. 2008.

HUXLEY, Rachel et al. Body mass index, waist circumference and waist: hip ratio as predictors of cardiovascular risk - a review of the literature. European Journal of Clinical Nutrition, London, v. 64, n. 1, p. 16-22, Jan. 2010.

KRAMER, Caroline K et al. A Prospective Study of Abdominal Obesity and Coronary Artery Calcium Progression in Older Adults. The Journal of Clinical Endocrinology \& Metabolism, Springfield, IL, v. 94, n. 12, p. 5039-5044, Dec. 2009. 
LEE, Crystal Man Ying et al. Indices of abdominal obesity are better discriminators of cardiovascular risk factors than BMl: a meta-analysis. Journal of Clinical Epidemiology, Oxford, New York, v. 61, n. 7, p. 646-653, Mar. 2008.

LEE, Young-Hoon et al. Metabolic syndrome and carotid artery parameter in Koreans aged 50 years and older. Circulation Journal, Kyoto, v. 74, n. 3, p. 560-566, Mar. 2010.

LEITE, Neiva et al. Associação entre o perfil lipídico e medidas antropométricas indicadoras de adiposidade em adolescentes. Revista Brasileira de Cineantropometria \& Desempenho Humano, Florianópolis, v. 11, n. 2, p. 127-133, 2009.

LU, Bing et al. Abdominal obesity and peripheral vascular disease in men and women: a comparison of waist-to-thigh ratio and waist circumference as measures of abdominal obesity. Atherosclerosis, Amsterdam, v. 208, n. 1, p. 253-257, Jan. 2010.

MARQUES, Elisa et al. Effects of resistance and multicomponent exercise on lipid profiles of older women. Maturitas, Limerick, v. 63, n. 1, p. 84-88, Apr. 2009.

PARDINI, Renato et al. Validação do questionário internacional de nível de atividade física (IPAQ - versão 6): estudo piloto em adultos jovens brasileiros. Revista Brasileira de Ciência e Movimento, Taguatinga, v. 9, n. 3, p. 45-51, July 2001.

PERISSINOTTO, Egle et al. Anthropometric measurements in the elderly: age and gender differences. British Journal of Nutrition, Wallingford, v. 87, n. 2, p. 177-186, Feb. 2002.

REZENDE, Fabiane Aparecida Canaan et al. Índice de Massa Corporal e Circunferência Abdominal: Associação com Fatores de Risco Cardiovascular. Arquivos Brasileiros de Cardiologia, São Paulo, v. 87, n. 6, p. 728-734, Dec. 2006.

RIGO, Julio Cesar et al. Prevalência de síndrome metabólica em idosos de uma comunidade: comparação entre três métodos diagnósticos. Arquivos Brasileiros de Cardiologia, São Paulo, v. 93, n. 2, p. 85-91, Aug. 2009.

SAAD, Maria Auxiliadora Nogueira et al. Prevalência de Síndrome Metabólica em Idosos e Concordância entre Quatro Critérios Diagnósticos. Arquivos Brasileiros de Cardiologia, São Paulo, v. 102, n. 3, p. 263-269, Mar. 2014.

SAS INSTITUTE. Statistical Analysis System. Version 9.1.3, Service Pack 3. Operating system: Microsoft Windows. Cary, NC, 2004.

SCAFOGLIERI, Aldo et al. Reproducibility, accuracy and concordance of Accutrend® Plus for measuring circulating lipid concentration in adults. Biochemia Medica, Zagreb, v. 22, n. 1, p. 100-108, Feb. 2012.

SONATI, Jaqueline Girnos et al. Body composition and quality of life (QoL) of the elderly offered by the "University Third Age" (UTA) in Brazil. Archives of Gerontology and Geriatrics, Amsterdam, v. 52, n. 1, p. 31-35, Jan./Feb. 2010.

SPOSITO, Andrei C. et al. IV Diretriz Brasileira sobre Dislipidemias e Prevenção da Aterosclerose: Departamento de Aterosclerose da Sociedade Brasileira de Cardiologia. Arquivos Brasileiros de Cardiologia, São Paulo, v. 88, p. 2-19, Apr. 2007. Supplement 1.

TULL, Eugene S.; THURLAND, Anne; LaPorte, Ronald E. Metabolic syndrome among Caribbean-born persons living in the U.S. Virgin Islands. Revista Panamericana de Salud Pública, Washington, D.C., v. 18, n. 6, p. 418-426, Dec. 2005.

WELSH, Jean A. et al. Caloric Sweetener Consumption and Dyslipidemia Among US Adults. JAMA, Chicago, v. 303, n. 15, p. 1490-1497, Apr. 2010.

WORLD HEALTH ORGANIZATION; FOOD AND AGRICULTURE ORGANIZATION OF THE UNITED NATIONS. Diet, nutrition and the prevention of chronic diseases. Report of a Joint WHO/FAO Expert Consultation. World Health Organization Technical Report Series, Geneva, n. 916, p. 1-160, Jan./Feb. 2002. 